\title{
鷹部屋福平「毛民青屋集」に基づいた 1940年の白老村アイヌ集落に見られた建築物の実態 ACTUAL CONDITIONS OF ARCHITECTURAL STRUCTURES OF AINU SETTLEMENT AT SHIRAOI IN 1940, BASED ON “COLLECTION OF THATCHED-ROOF HOUSES OF THE AINUS” BY FUKUHEI TAKABEYA
}

\author{
佐久間 学*, 羽深久夫**
}

Manabu SAKUMA and Hisao HABUKA

\begin{abstract}
The Shiraoi Village Ainu settlement that Takabeya investigated in 1940 was divided among the villagers such that each Ainu family household was allotted one section of land. Houses belonging to "village chief/equivalent" villagers had elongated floor space and both the main and auxiliary structures were larger in scale than those belonging to the "other people" villagers. Furthermore, "village chief/equivalent" villagers owned structures. "Other people" villagers did not possess such structures and what they did possess was apparently intended only for habitation. It is also possible that gabled roof houses were used both for habitation as well as for auxiliary activities. In addition, there were traits common among the houses of both groups. For example, construction was arranged such that houses had their longer axis parallel to the east-west axis of the settlement.
\end{abstract}

Keywords : Ainu people, Houses(Chise), Attached buildings, Settlement(Kotan), Shiraoi アイヌ民族，住居（チセ），付属建築物，集落（コタン），白老

\section{1. 研究の背景と目的}

1940 年における白老村アイヌ集落（図 1）は、1889 年に胆振国 白老郡白老村字古潭（現在の白老町大町 1 丁目）に給与地が指定さ れ、ウヨロ、ブーベッ方面に散在していたアイヌ民族が移住させら れたことから始まる ${ }^{1)}$ 。1911 年の東宮殿下（後の大正天皇）の白 老村の来訪を契機に、白老村はアイヌ民族の居住地区として知られ るようになり、多くの皇族や研究者が来訪した ${ }^{2)}$ 。アイヌ民族の建 築に関する研究の第一人者である鷹部屋福平氏 ${ }^{3)}$ も、1940 年に白 老村アイヌ集落を来訪し、23 棟の建築物についてその写真と平面 図を後世に残寸資料として「毛民青屋集 ${ }^{4)} 」 7 \sim 8$ に記録している。 その後も観光客は増加し、環境的に適切な場所一の移設が求められ るようになり、白老村アイヌ集落は、1965 年にポロト湖畔に移転

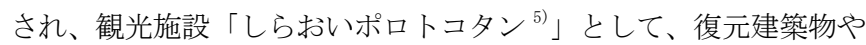
博物館を建設し、アイヌ民族の文化の保護と後世への継承を担って いる。白老村アイヌ集落のあった大町 1 丁目は、区画整備され、住 宅地となり現在に至る。

「毛民青屋集」7〜8は、「しらおいポロトコタン」に復元されて いるアイヌ民族の伝統的な建築物 ${ }^{6)}$ と考えられている茅壁茅蒀屋 根の寄棟建築物だけではなく、ガラス空やマサ壁を設けた外観を 持つ寄棟建築物も収録している事から、同化政策の影響が現れた 1940 年当時のアイヌ民族の建築物 ${ }^{7)}$ の実態を考察でき、また、集
落単位で建築物を収録している事から、建築物の外観や平面規模の 比較ができる。鷹部屋氏の白老村アイヌ集落に関する研究 ${ }^{8)}$ を見 ると、北海道の各地に存在したアイヌ民族の建築物の地域性に関寸 る研究において、白老村アイヌ集落を例にあげ、現地調査と古老へ の聞取り調査から小屋組構造等の特徵について考察している。しか し、研究内容は、1940 年までに見られたアイヌ民族の建築物の伝

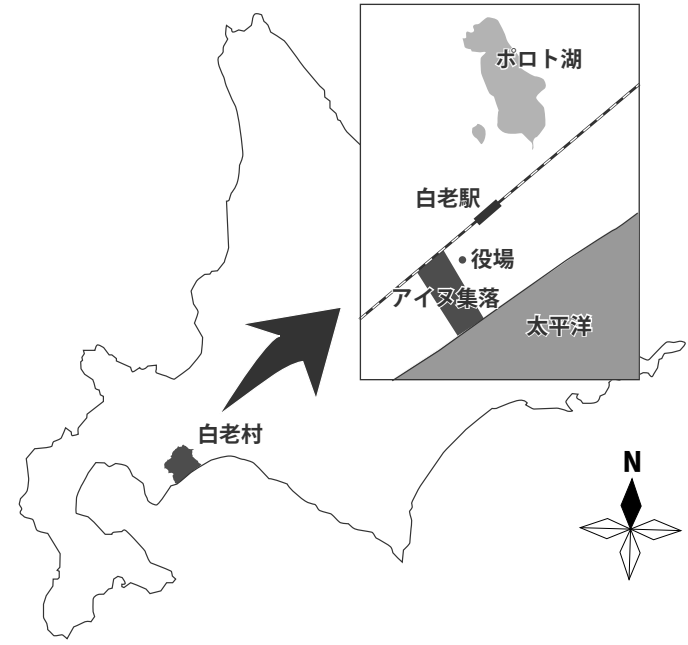

図 11940 年当時の白老村アイヌ集落の位置
* 札幌市立大学大学院デザイン研究科 博士後期課程・修士 (デザイン学)

** 札幌市立大学大学院デザイン研究科 教授・博士 (工学)
Graduate Student, Graduate School of Design, Sapporo City University, M. Des. Prof., Graduate School of Design, Sapporo City University, Dr. Eng. 
統的な側面についてであり、また、平面図を残しているがそれらを 用いた研究や白老村アイヌ集落内の建築物を比較した研究は見られ ない。鷹部屋氏以外のアイヌ民族の建築物に関する研究 ${ }^{9)}$ を見ても、 研究の対象となったのは伝統的なアイヌ民族の建築物であり、同化 政策の影響が見られるアイヌ民族の建築物も研究対象とし、同一集 落内の建築物を比較した研究は見られない。

本研究は、「毛民青屋集」7〜8 を基にして、古地図や空中写真 といった白老村アイ又集落を記録した資料を検討する事により、白 老村アイヌ集落の土地区画の特徵と鷹部屋氏の調査した居住地と建 築物を明らかにし、建築物の屋根形状や外観意匠や入口と空の位置 といった外観の特徵、平面形や延べ床面積といった平面規模の特徵、 及び建築物の所有状況を分析し、1940 年当時の白老村アイヌ集落 の建築物の実態を明らかにする。

\section{2. 資料について}

\section{（1）「毛民青屋集」7 8}

「毛民青屋集」7〜8は、調査票 112 枚、人名表 1 枚からなる。 調查票は、建築物の外観写真、中央に写る建築物の居住者名、寸法・ 空と入口の位置・居住者名が記載された平面図からなる。人名表は、 アイヌ居住者名 24 名を地図に記載したものである。

人名表に記載の有る 24 名の内、建築物の写真と平面図の収録が あるのは 20 名であり、残りの 4 名については写真も平面図も収録 されていない。収録されている 20 名は、住居 1 棟と納屋 1 棟の所 有者が 2 名、住居 2 棟の所有者が 1 名、住居 1 棟の所有者が 17 名 であり、建築物数の合計は、住居 21 件、納屋 2 件の 23 件で、 23 件全てが「平地式の茅亘屋根の寄棟建築物（以下、平地式寄棟建築 物)」である。その他、「平地式寄棟建築物」の周辺には、人名表に 記載の無い「平地式の茅莫屋根の切妻建築物（以下、平地式切妻建
築物)」7 件、人名表に記載の有る「住居に付属する建築物（以下、 付属建築物)」として、「高床倉庫」が 4 件、「熊檻」が 6 件、「イナ $\dot{n}^{10)} 」$ が 3 件ある。本研究は、20 名の居住者及び、20 名の居住者 が所有する「平地式寄棟建築物」 23 件、「平地式切妻建築物」 7 件、 「付属建築物」 13 件の合計 43 件の建築物を研究対象とする。

表 1 は調査票の記載内容をまとめたものであり、表記方法は以下 の通りである。建築物は、「平地式寄棟建築物」を「口」、「平地式 切妻建築物」を「山」、付属建築物」を「○」とした。人名表に記 載のある「平地式建築物」及び「付属建築物」について、アイヌ民 族の所有者名は「01〜20」の数字番号で表記し、用途別に住居を「H」、 物置を「S」、高床倉庫を「P」、熊檻を「B」、イナウを「I」と表記 した。「平地式切妻建築物」の名称は、「 $\mathrm{a} \sim \mathrm{g}\rfloor$ の文字アルファベッ トで表記した。

\section{（2）その他の資料}

本研究は、白老村アイヌ集落の土地区画を明らかにするため、以 下の資料を用いた。

(1)「胆振国白老郡白老村字コタン旧土人下附実測図 ${ }^{11)} 」($ 以下、下 附実測図)

下附実測図は、1912 年に作製された 1200 分の 1 の白老村アイヌ 集落の実測図であり、給与地区画とその土地の所有者名が記入さ れている。下附実測図から、1912 年における白老村アイヌ集落は、 360 坪（12 間 $\times 30$ 間） 2 区画と 450 坪（15 間× 30 間） 90 区画と 630 坪 (15 間 $\times 42$ 間) 4 区画の計 96 区画で整備された事が分かる。 96 区画の内 67 区画は給与地としてアイヌ民族に割り渡され、残り の 29 区画は所有者がいなかった。道路は、道路幅が 5 間の南北道 路 2 本と東西道路 3 本を基本とし、その他、南北道路を繋ぐ道路幅 3 間の東西道路が 1 本あった。アイヌ民族以外の所有地は、96 区 画外の集落北部の国鉄室蘭本線線路付近にあった。

表 1 調査票の記載内容
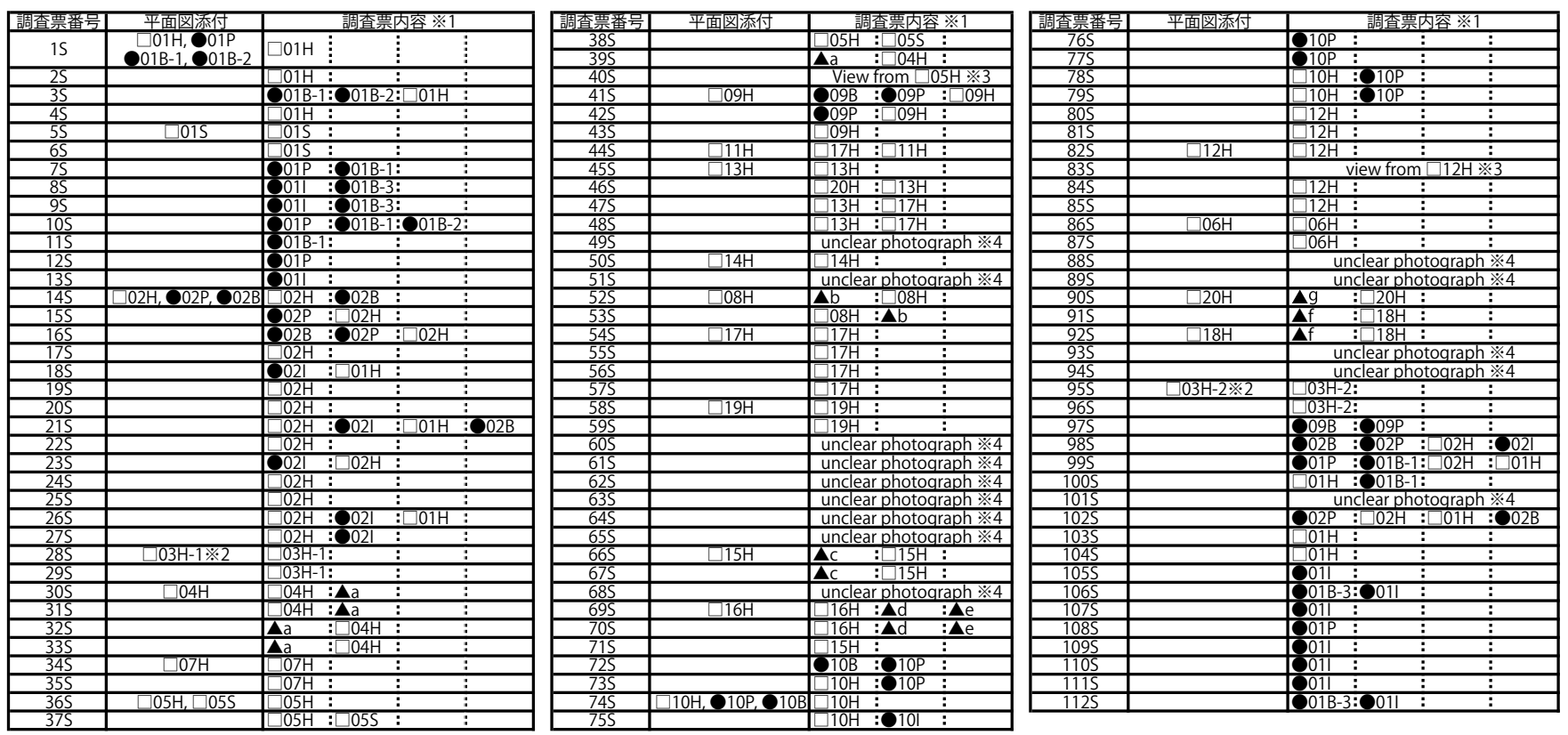

※ 1 調査票内容は、写真に写る建築物を左から順に表記したものである。

※2 $\square 03 \mathrm{H}-1$ と $\square 03 \mathrm{H}-2$ は場所は離れているが居住者は同じである。

※3 調査票番号「40S」は建築物「口05H」から、調査票番号「83S」は建築物「口12H」から見た風景写真である。

※ 撮影場所の分からない写真を指す。 
(2)「新白老町史下巻 - 昭和初期白老アイヌコタン図 $-{ }^{12)} 」($ 以下、 コタン図)

コタン図は新白老町史に添付されている白老村アイヌ集落の建築 物とその所有者を記載した地図である。1937 年までに白老村アイ 又集落内に存在した白老第 2 小学校や北海道庁立白老病院を記載 していることから、コタン図は1926 年から 1937 年の地図である。 コタン図から、1926 年から 1937 年における白老村アイヌ集落は、 84 名（世帯）のアイヌ民族の住居があった事が分かる ${ }^{13)}$ 。

\section{(3)「国土地理院所蔵空中写真 ${ }^{14)} 」($ 以下、空中写真)}

1944 年撮影の空中写真は、現在国土地理院が所蔵する入手可能 な白老村を写す空中写真の中、鷹部屋氏が調査した 1940 年に最も 近い状況を写し込んでおり、建築物が存在した場所の把握ができる。 下附実測図の全 6 本の道路は、空中写真においても同一の場所に見 られ、6 本以外の道路は空中写真にも見られないので、道路割りは 変化していない。

\section{3. 白老村アイヌ集落の土地区画}

図 2 は、1940 年の鷹部屋氏が調査した 20 名の居住地と、1937 年まで存在した白老第 2 小学校と北海道庁立白老病院を 1912 年の 下附実測図に配置したもので、図 2 を基に白老村アイヌ集落の土地 区画の特徵と鷹部屋氏の調査した居住地と建築物を明らかにする。

\section{（1）土地区画図の作製（図 2）}

1912 年の土地区画は、1912 年時に所有者のいない給与地区画（以 下、区画「a」）、1912 年時にアイヌ民族に割り渡された給与地区画 (以下、区画「b」）、1912 年時において給与地区画外の区画（以下、 区画「c」）、アイヌ民族以外の所有地区画（以下、区画「d」）の 4 つである。調査対象 20 名の居住地の特定について、調查対象 20 名の居住地を 1912 年の土地区画に当てはめると、居住地の区画は、 18 名が 1 区画、2 名（居住者「01」と「03」）が 2 区画を利用して いるため、合計 22 区画となる。 22 区画の内 12 区画は、下附実測 図の各区画の姓と人名表に記される所有者の姓の記名位置が一致す る居住地（以下、居住地「A」）であり、1912 年と 1940 年で同じ所 有者 (家系) の区画「b」と考えられる。残り 10 区画の内、6 区画 はコタン図の姓と人名表に記される所有者の姓の記名位置が一致す る居住地（以下、居住地「B」）であり、4区画は人名表のみに記載 のある居住地（以下、居住地「C」）である。人名表の所有者名が下 附実測図に記されていない居住地「B」及び居住地「C」の計 10 区 画の 1912 年の土地区画上の位置は、コタン図及び人名表の記名位 置や、居住地の特定された建築物と居住地の特定されない建築物の 両方が写り込む写真からの位置関係（表 1 を利用）や、鷹部屋氏 の調查後の撮影であるが 1944 年の空中写真に写る建築物の位置関 係により行った。この 10 区画の 1912 年の土地区画上での内訳は、 区画「a」が 2 つ、区画「b」が 4 つ、区画「c」が 4 つ（区画「c」 の B-03、B-16、B-20、C-19について、土地区画の坪数は分からな いが 450 坪として図 2 に表記している) である。

\section{（2）土地区画の特徵}

白老村アイヌ集落の土地区画は、北は国道、南は太平洋に至る 2 本の南北道路（南北軸から反時計回りに凡そ 30 度の傾きがある） と南北道路に垂直な 4 本の東西道路が交わった土地に対し、1 区画 450 坪（15 間× 30 間）を基本に区画整備されていた。

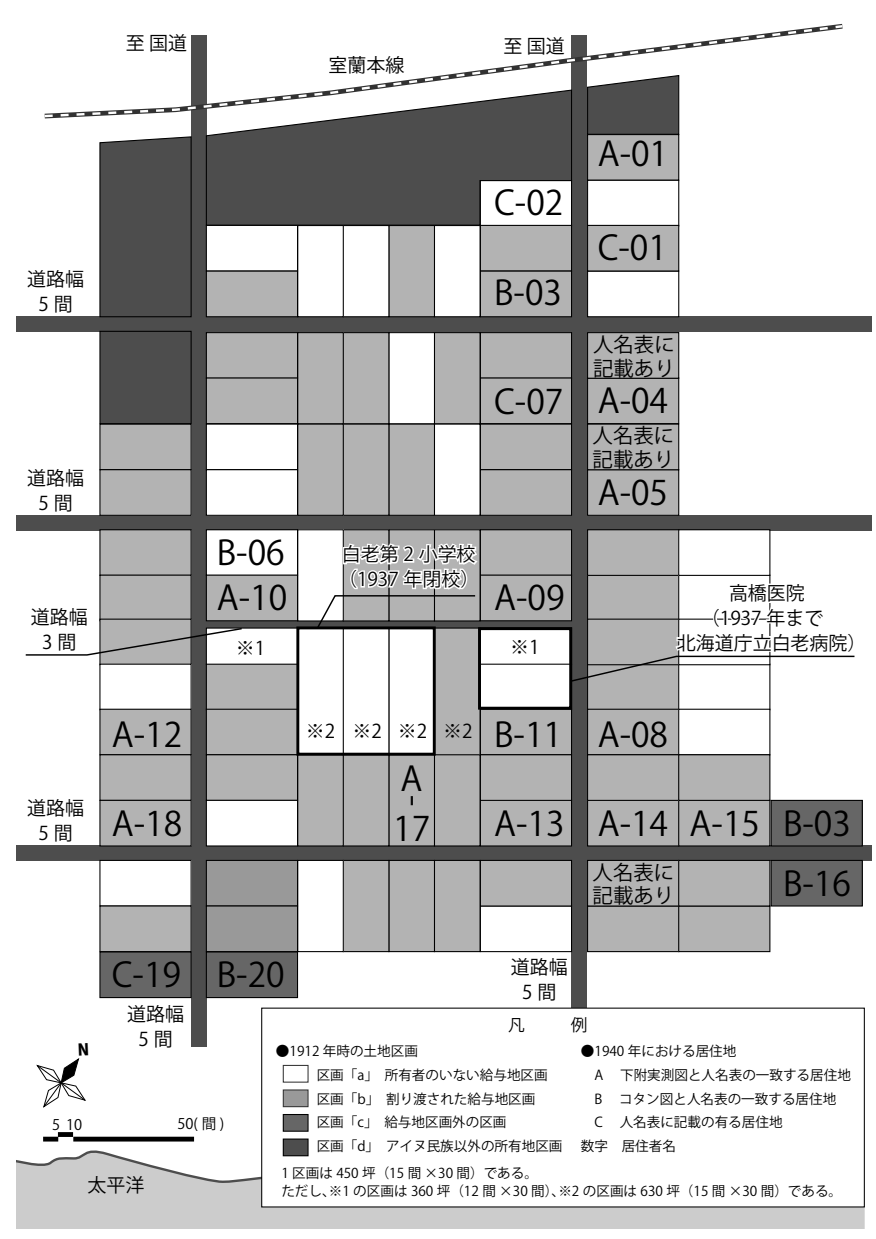

図 2 土地区画図

1912 年において、白老村アイヌ集落は 96 区画で整備されていた が、鷹部屋氏が調査を行った 1940 年には、96 区画の外側（区画「c」） にもアイヌ民族が住んでいた事が分かる。鷹部屋氏が調査した 20 名の内 18 名は 1 区画の所有であることから、割り渡された給与地 は 1 世帯に 1 区画（坪数は凡そ 450 坪）を基本としていたと考え られる。白老第 2 小学校は 630 坪の 3 区画、北海道庁立白老病院 は 360 坪と 450 坪の 2 区画に位置し、共に 1912 年以後に区画「a」 に建てられた事が分かる。1937 年に両施設が旧土人保護法の改正 に伴い廃止された後は、小学校は跡地が残り、病院は高橋医院とし て開業した ${ }^{15)}$ 。

\section{（3）鷹部屋氏の調査した居住地と建築物}

鷹部屋氏は、1912 年時の土地区画 96 区画と 1940 年当時に少な くとも建築物のあった 4 区画（区画「c」）の計 100 区画の内 23 区 画、世帯数ではコタン図にある凡そ 84 名（世帯）の内 20 名（世帯） を調查した。20 名が所有した建築物は、1940 年時においてアイヌ 民族が使用していた建築物であり、特に鷹部屋氏は小屋組構造を中 心に研究した事から、屋根に茅莫が見られる寄棟屋根の建築物を中 心に調査した事が窥える。

\section{4. 平地式寄棟建築物の特徵}

「平地式寄棟建築物」 23 件について、平面形と延べ床面積、外観 意匠、入口と空の位置を分析し（表 2)、「平地式寄棟建築物」の特 徵を明らかにする。 
（1）平面形と延べ床面積

平面形は、主屋とセム ${ }^{16)}$ の接続位置とセムの規模から大きく $4 つ$ に分類し (図 3、図 4)、各平面形の延心床面積をまとめた ${ }^{17}$ 。

(1)平面形 a

平面形 $\mathrm{a}$ は、セムを伴わない平面形であり、妻入が 2 件、平入が 10 件の計 12 件 (平地式寄棟建築物 23 件の内、件数比 $52.2 \%$ ) である。 延べ床面積は、8. $84 \mathrm{~m}^{2} \sim 96.36 \mathrm{~m}^{2}$ まであり、30.00 m²満が 4 件 (内 1 件は納屋)、 $30 \mathrm{~m}^{2}$ 以上 $50 \mathrm{~m}^{2}$ 未満が 7 件、 $70 \mathrm{~m}^{2}$ 以上が 1 件である。 納屋である「口05S」の延べ床面積は、8.84 m² と住居より小さい。 (2)平面形 $b-1$

平面形 $b-1$ は、主屋の平側に小庇程度のセムが接続し、平入の 平面形である。セムの屋根形状は、片流れ屋根が 5 件、切妻屋根が 2 件の計 7 件 (平地式寄棟建築物 23 件の内、件数比 $30.4 \%$ ) である。 セムの面積は $0.80 \mathrm{~m}^{2} \sim 8.46 \mathrm{~m}^{2}$ 、延べ床面積は $26.16 \mathrm{~m}^{2} \sim 59.03$ $\mathrm{m}^{2}$ まであり、 $30.00 \mathrm{~m}^{2}$ 未満が 1 件 (納屋)、 $30 \mathrm{~m}^{2}$ 以上 $50 \mathrm{~m}^{2}$ 未満が 3 件、 $50 \mathrm{~m}^{2}$ 以上 $70 \mathrm{~m}^{2}$ 未満が 3 件である。

\section{(3)平面形 $b-2$}

平面形 $b-2$ は、主屋の妻側に小庇程度のセムが接続し、セムは平 入、主屋は妻入の平面形で 1 件 (平地式寄棟建築物 23 件の内、件 数比 $4.35 \%$ ） ある。セムの屋根形状は片流れ屋根であり、セムの 面積は $1.63 \mathrm{~m}^{2}$ 、延べ床面積は $24.24 \mathrm{~m}^{2}$ である。

\section{(4)平面形 $\mathrm{c}$}

平面形 c は、主屋の妻側に玄関（室）としてセムを接続し、セム は平入、主屋は妻入の平面形で 3 件（平地式寄棟建築物 23 件の内、 件数比 $13.0 \%$ ） ある。セムの屋根形状は寄棟屋根であり、セムの 面積は $12.09 \mathrm{~m}^{2} \sim 15.60 \mathrm{~m}^{2}$ 、延べ床面積は $72.81 \mathrm{~m}^{2} \sim 82.94 \mathrm{~m}^{2}$ で ある。

\section{（2）外観意匠}

建築物 23 件の屋根は全て段々に仕上げた茅莫きである。壁は、「茅 壁」が 17 件（件数比 $73.9 \%$ )、「マサ壁」が 6 件（件数比 $26.1 \%$ ) である。空の有る 22 件の建築物の空の莫口は、「茅蓋と木蓋」が 1 件、「木蓋」が 5 件、「ガラス空」が 10 件、「覆い無し」が 5 件、「不

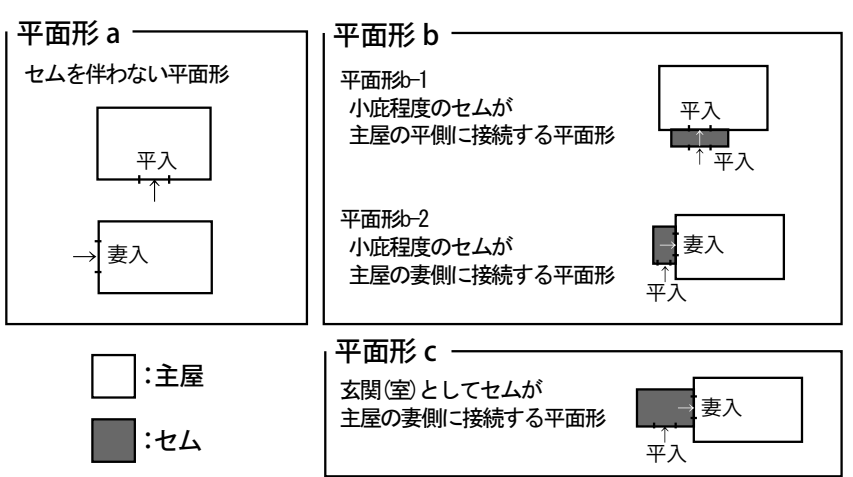

図 3 平地式寄棟建築物の平面形
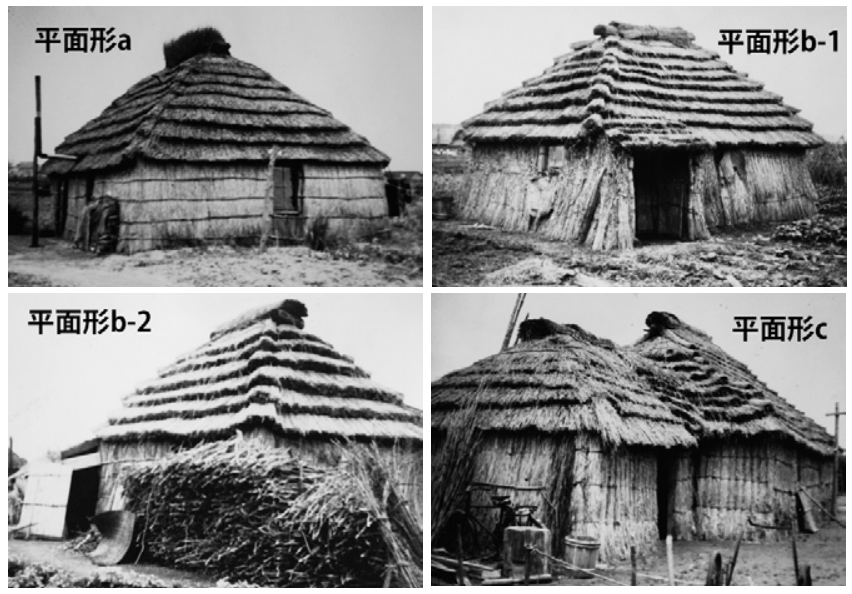

図 4 平地式寄棟建築物の立面写真

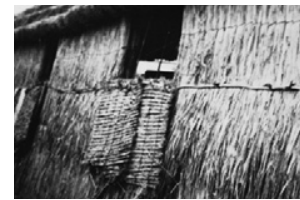

茅蓋

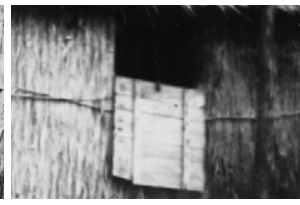

木蓋
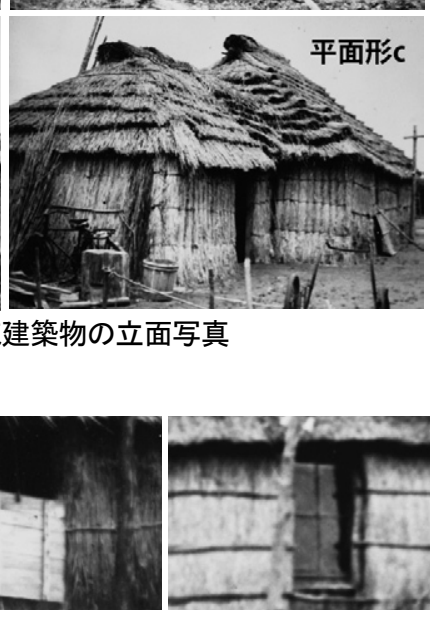

ガラス空
図 5 空の葺口

表 2 平地式寄棟建築物の特徵

\begin{tabular}{|c|c|c|c|c|c|c|c|c|c|c|c|c|c|c|}
\hline \multirow{2}{*}{ 建築物 } & \multicolumn{4}{|c|}{ 平面形の分類 } & \multicolumn{3}{|c|}{ セムの規模と形状 } & \multicolumn{3}{|c|}{ 主屋の規模 } & \multirow{2}{*}{$\begin{array}{l}\text { 延べ床 } \\
\text { 面積 }\left(\mathrm{m}^{2}\right)\end{array}$} & \multicolumn{2}{|c|}{ 外観意匠 } & \multirow{2}{*}{ 空位置※3 } \\
\hline & 分類 & セムの位置 & セムの入口| & 主屋の入口 & 面積(m²) & 機能 & 屋根形状 & 長辺(m) & 短辺 (m) & 面積(m²) & & 壁 & 窓※2 & \\
\hline $\mathrm{J} 01 \mathrm{H}$ & 平面形 & & & 妻入 & 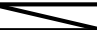 & & & 13.2 & 7.3 & 96.36 & 96.36 & 茅壁 & 茅蓋と木蓋 & 南2東1 \\
\hline $03 \mathrm{H}-2$ & 平面形a & & & 妻入 & & & & 7.0 & 6.1 & 42.70 & 42.70 & 茅壁 & 覆い無し & 南1 \\
\hline $03 \mathrm{H}-1$ & 平面形 & 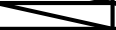 & & 平入 & & & & 8.0 & 6.0 & 48.00 & 48.00 & 茅壁 & ガラス梥 & 南1東1 \\
\hline $006 \mathrm{H}$ & 平面形a & & & 平入 & & & & 7.4 & 5.9 & 43.66 & 43.66 & マ开壁 & 木蓋 & 南1東1 \\
\hline $111 \mathrm{H}$ & 平面形a & 7 & 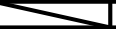 & 平入 & 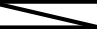 & 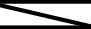 & & 6.5 & 5.2 & $37.70 \% 1$ & 37.70 & 茅壁 & 覆い無し & 南1西1東1 \\
\hline $2 \mathrm{OH}$ & 平面形a & - & & 平入 & & & & 7.0 & 4.8 & 33.60 & 33.60 & 茅壁 & 覆い無し & 南1東1 \\
\hline $12 \mathrm{H}$ & 平面形a & & & 平入 & & & & 6.0 & 5.4 & 32.40 & 32.40 & マ䜃 & ガラス窓 & 南1東1 \\
\hline $13 \mathrm{H}$ & 平面形 & & & 平入 & & & & 6.0 & 5.2 & 31.20 & 31.20 & 茅壁 & 木蓋 & 南1東1 \\
\hline $18 \mathrm{H}$ & 平面形a & 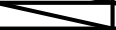 & & 平入 & & & & 5.3 & 3.7 & 19.61 & 19.61 & 茅壁 & 木蓋 & 南1東1 \\
\hline $17 \mathrm{H}$ & 平面形a & & & & & & & 3.6 & 3.5 & 12.60 & 12.60 & 茅壁 & 覆い無し & 南1東1 \\
\hline $05 \mathrm{~S}$ & 平面形a & & & 平入 & & & & 3.4 & 2.6 & 8.84 & 8.84 & 茅壁 & 窓なし & 窓なし \\
\hline $\mathrm{J08 \textrm {H }}$ & 平面形 $\mathrm{b}-1$ & 主屋平偩 & 平入 & & 1.80 & 小庇 & 片流れ & 9.7 & 5.9 & 57.23 & 59.03 & マサ壁 & ガラス窓 & 南1東1 \\
\hline 104H & 平面形 $\mathrm{b}-1$ & 主屋平側 & & & 1.68 & 小庇 & 原流れ & 8.8 & 5.7 & 50.16 & 51.84 & 茅壁 & ガラス梥 & 南2東1 \\
\hline $05 \mathrm{H}$ & 平面形 $\mathrm{b}-1$ & 主屋平側 & 平入 & $-\lambda$ & 0.80 & 小庇 & 片流れ & 7.4 & 6.5 & 48.10 & 48.90 & 茅壁 & 夯ラス憲 & 南1西1東1 \\
\hline $\mathrm{J14 \textrm {H }}$ & 平面形 $\mathrm{b}-1$ & 主屋平側 & 平入 & 平入 & 1.70 & 小庇 & 片流れ & 6.8 & 5.3 & 36.04 & 36.74 & マ壁 & ガラス窓 & 南1東1 \\
\hline 015 & 平面形 $\mathrm{b}-1$ & 主屋平側 & 平入 & 平入 & 1.80 & 小庇 & 片流れ & 5.8 & 4.2 & 24.36 & 26.16 & 茅壁 & ガラス窓 & 南1西1東1 \\
\hline$\square 16 \mathrm{H}$ & 平面形b-1 & 主屋平側 & 平入 & 平入 & 8.36 & 小庇 & 切妻 & 7.6 & 5.8 & 44.08 & 52.44 & マ年壁 & 不明 & 南1東1 \\
\hline $\mathrm{D15 \textrm {H }}$ & 平面形 $\mathrm{b}-1$ & 主屋平側 & 平入 & 平入 & 1.56 & 小庇 & 切妻 & 7.4 & 5.7 & 42.18 & 43.74 & マ开壁 & カララス窓 & 南1東1 \\
\hline $07 \mathrm{HH}$ & 平面形b-2 & 主屋妻側 & 平入 & 妻入 & 1.63 & 小庇 & 片流れ & 4.7 & 4.3 & $22.61 \% 1$ & 24.24 & 茅壁 & 覆い無し & 南1 \\
\hline$\square 10 \mathrm{H}$ & 平面形c & 主屋妻側 & 平入 & 妻入 & 17.20 & 玄関(室) & 寄棟 & 8.0 & 7.6 & 60.80 & 78.00 & 茅壁 & 木蓋 & 南2東1 \\
\hline$\square 09 \mathrm{H}$ & 平面形c & 主屋妻側 & 平入 & 妻入 & 12.09 & 玄関(室) & 寄棟 & 8.8 & 6.9 & 60.72 & 72.81 & 茅壁 & ガラス冡 & 南2東1 \\
\hline
\end{tabular}

※ 1 長方形平面の面積の他，平側の突出する下屋部の面積も含む。 $※ 2$ 空の表記について、「茅蓋」は公を茅で覆うもの、「木蓋」は公を木材で覆うもの、「ガラス空」 は木空枠にガラス空を設置しているもの、「覆い無し」は空が覆われていなく開いた状態のもの、「不明」は空が写真に写らないものをさす。※ 3 空位置の表記について、 「南 2 東 $1 」 を$ 例にとると、南面に窓が 2 つ東面に空が 1 つを設置している事を指す。 
明」が 1 件である（図 5)。

\section{(3) 入口と空の位置 ${ }^{18)}$}

建築物 23 件の建築物の配置は主屋長軸が各土地区画の東西軸に あたり、入口は平入では南で妻入では西に位置している。空の位置 は、「南面に空を 1 つ東面に空を 1 つ設置（以下、「南 1 東 $1 」$ の様

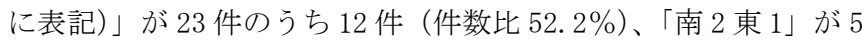

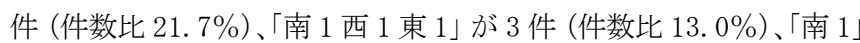
が 2 件（件数比 $8.7 \%$ )、「空無し」が 1 件（件数比 $4.3 \%$ ）である。

\section{5. 平地式切妻建築物の特徵（表 3）}

「平地式切妻建築物」 7 件は、所有者を特定し、平面形、外観意匠、 平面規模の特徵を明らかにする。「平地式切妻建築物」は「平地式 寄棟建築物」と同じ区画内の西側に存在し、隣接する「平地式寄棟 建築物」の所有者の建築物と考えられることから、所有者を表 3 の

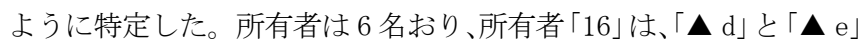
2 件を所有している (図 6)。平面形は、セムの伴わない矩形で、入 口は平入を 1 件、妻入を 1 件で、その他 5 件は不明である。壁は 7 件全て茅壁であり、空は設けていない。延べ床面積は、平面図が無 いため写真から判断すると、隣接する「平地式寄棟建築物」より小 さい。

\section{6. 付属建築物の特徵}

「高床倉庫」 4 件、「熊檻」 6 件、「イナウ」 3 件の「付属建築物」 について、「高床倉庫」及び「熊檻」は構造、平面形、外観意匠、 平面規模の特徵を明らかにし、「イナウ」は設置位置の特徴を明ら かにする。

\section{(1)高床倉庫（表 4、図 7)}

「高床倉庫」 4 件は、柱を建て込み高床を設け、その上に檻本体 を乗せた、高床と倉庫が分離している建築物（高床式・分離型）で ある。平面形は、短辺が 1 間で長辺が 1 間の 4 本柱からなるものが 2 件、短辺が 1 間で長辺が 2 間の 6 本柱からなるものが 2 件である。 屋根形状は、寄棟屋根が 1 件、切妻屋根が 3 件である。壁及び屋根 の仕上げは全て茅莫、入口は全て妻側である。延べ床面積の分かる ものは 3 件あり、 $2.25 \mathrm{~m}^{2} \sim 4.37 \mathrm{~m}^{2}$ である。

(2)熊檻（表 5、図 8)

「熊檻」 6 件は、柱を建て込み高床を設け、その上に檻本体を乗せ た高床と檻が分離している構造（高床式・分離型）が 4 件、柱を 建て込み高床を設け周囲に丸太を井桁状に組む構造（高床式・一体 型）が 1 件、柱を建て込み、地上から周囲に丸太を井桁状に組む構 造（平地式・一体型）が 1 件である。柱数と柱間数は、全て柱数 4 本で柱間数が短辺が 1 で長辺が 1 である。檻は全て丸太材である。 檻上蓋の分かるものは 2 件あり、全て丸太を平行に並べる型である。 延べ床面積の分かるものは 4 件あり、 $1.40 \mathrm{~m}^{2} \sim 1.96 \mathrm{~m}^{2}$ である。

\section{(3)イナウ}

「イナウ」を確認できる居住者は「01」「02」「10」の 3 名であり、 「イナウ」は住居の東側に位置し、住居の東空（神空）から「イナウ」 をのぞくことができる。「イナウ」の配置位置について、 $\square 01 \mathrm{H} の$ 住居と「イナウ」までの距離は $8.0 \mathrm{~m}$ と鷹部屋氏が平面図に記録 している。
表 3 平地式切妻建築物の特徵

\begin{tabular}{|c|c|c|c|c|c|}
\hline 建築物 & 所有者 & 入口 & 壁 & 窓 & 平面規模 \\
\hline$\Delta \mathrm{a}$ & 04 & 平入 & 䋷壁 & 無 & ○04Hより小 \\
\hline$\Delta \mathrm{b}$ & 08 & 妻入 & 茅壁 & 無 & ○08Hより小 \\
\hline$\Delta c$ & 15 & 不明 & 茅壁 & 無 & 口15Hより小 \\
\hline$\overline{\Delta d}$ & 16 & 不明 & 茅壁 & 無 & 口16Hより小 \\
\hline $\bar{\Delta} \mathrm{e}$ & 16 & 不明 & 蓩壁 & 無 & प16Hより小 \\
\hline $\bar{\Delta} f$ & 18 & 不明 & 䋷壁 & 無 & 士18Нより小 \\
\hline$\Delta g$ & 20 & 不明 & 茅壁 & 無し & प20Hより小 \\
\hline
\end{tabular}

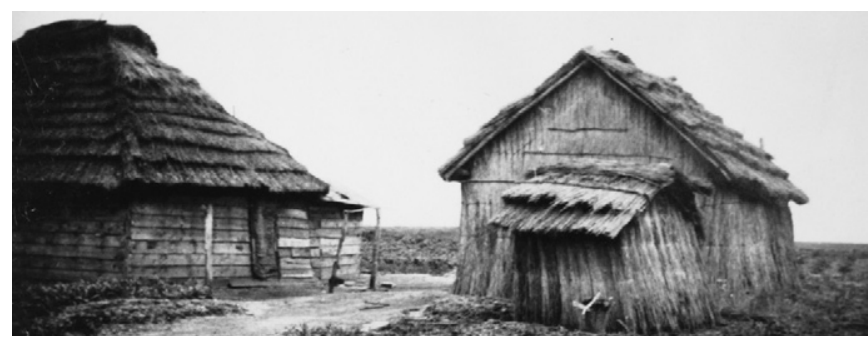

図 62 件の「平地式切妻建築物」の所有状況（調査票 695 の写真）

表 4 高床倉庫の特徵

\begin{tabular}{|c|c|c|c|c|c|c|c|c|c|c|}
\hline 建築物 & 構造 & 柱数 & $\frac{\text { 枉 }}{\text { 知证 }}$ & 数 & 屋根形状 & 壁 & 入口 & 長辺 $(m)$ & 短辺(m) & 面積(m) \\
\hline$\overline{0011}$ & 高床式・分離开 & 4 & & $\frac{1}{1}$ & 切妻 & 茅壁 & 妻入 & 2.3 & 1.9 & 4.37 \\
\hline $02 \mathrm{P}$ & 高床式・ & $\frac{4}{4}$ & & $\frac{1}{1}$ & 切妻 & 茅壁 & 安入 & $\frac{2.5}{1.5}$ & $\frac{1.9}{1.5}$ & $\frac{4.31}{2.25}$ \\
\hline $09 \mathrm{P}$ & & $\frac{7}{6}$ & & $\frac{1}{2}$ & & 茅壁 & 安入 & 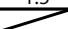 & 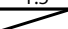 & \\
\hline$\frac{09 P}{10 P}$ & 厡式・分離型 & $\frac{5}{6}$ & & $\frac{2}{2}$ & 寄棟 & 柕垚 & 妾入 & 2.1 & 1.5 & 3.15 \\
\hline
\end{tabular}

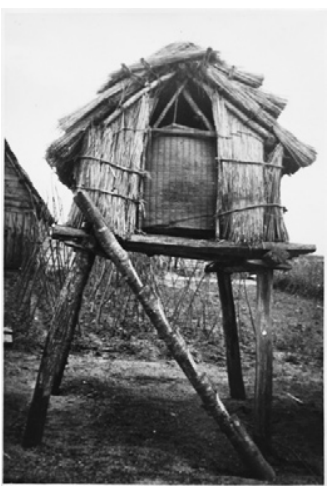

切妻屋根で 4 本柱

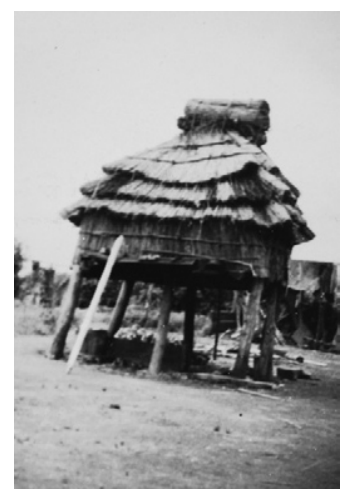

寄棟屋根で 6 本柱
表 5 熊檻の特徵

\begin{tabular}{|c|c|c|c|c|c|c|c|c|c|}
\hline 建築物 & 構造 & 柱数 & \multicolumn{2}{|c|}{$\begin{array}{c}\text { 枉間数 } \\
\text { 短边 }\end{array}$} & 檻上蓋 & 壁 & 長辺 $(\mathrm{m})$ & 短辺 $(m$ & 面積 $\left(\mathrm{m}^{2}\right)$ \\
\hline$\overline{01 B-1}$ & 高床式·分睢型 & 4 & $\frac{x+12}{1}$ & & 不明 & 丸太材 & \begin{tabular}{|l|}
1.4 \\
\end{tabular} & \begin{tabular}{|l}
1.0 \\
\end{tabular} & 1.40 \\
\hline & 高床式・分離型 & 4 & & & 不明 & 丸太材 & 1.4 & 1.0 & \\
\hline $2 \mathrm{~B}$ & 高㕅式·分離型 & 4 & 1 & & 丸太平行 & 丸太材 & 1.4 & 1.4 & 1.96 \\
\hline $10 \mathrm{~B}$ & 高床式・分離型 & 4 & 1 & 1 & 不明 & 丸太材 & 7 & 7 & 7 \\
\hline O9B & 高床式・一体 & 4 & & & 不明 & 丸太 & 1.2 & 1.2 & 1.44 \\
\hline $01 \mathrm{~B}-3$ & 平地式・一体型 & 4 & 1 & & 丸太平行 & 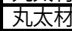 & & & 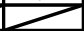 \\
\hline
\end{tabular}

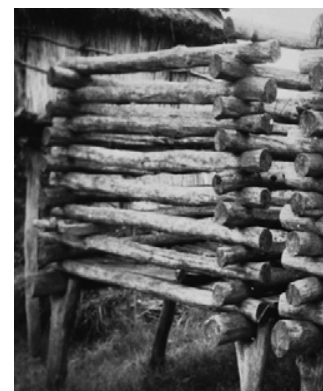

高床式 · 分離型

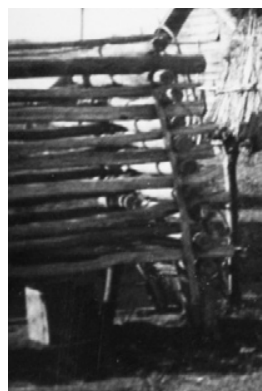

高床式 · 一体型

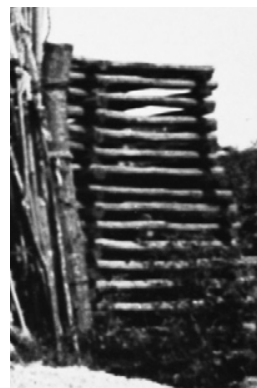

平地式 $\cdot$ 一体型 
7. 所有者別に見た建築物の所有状況と比較

\section{（1）建築物の所有状況（表 6)}

新白老町史 ${ }^{19)}$ には、白老村アイヌ集落のコタンコルクル（村長） の家系（本研究での居住者記号「01」、「10」）の記載があり、また、 1911 年の東宮殿下の白老村の来訪時に東宮殿下を案内したアイヌ 民族（「01」、「02」、「09」、「10」）の4名が記載されており、この 4 名は「村長及び村長に準ずる人 ${ }^{20)} 」$ と考えられる。白老村アイヌ

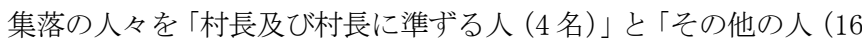
名)」に分類寸ると、建築物の所有状況は以下のようになる。

なお、第 3 章の土地区画と建築物の所有状況と鷹部屋氏が記録し た平面図から、居住者 20 名の計 43 件の建築物は配置図の作製が 可能であり（平面図の無い建築物は写真から建築物の位置関係や平 面規模を検討寸る必要がある)、本研究では図 9 〜図 12 の 4 例を 記している ${ }^{21)}$ 。

\section{(1)「村長及び村長に準ずる人」が所有する建築物}

「村長及び村長に準ずる人」の住居（ $\square$ 01H、 $\square 02 \mathrm{H} 、 \square 09 \mathrm{H} 、 \square$ $10 \mathrm{H})$ は、 $\square 01 \mathrm{H}$ は平面形 a で、 $\square 02 \mathrm{H} 、 \square 09 \mathrm{H} 、 \square 10 \mathrm{H}$ の 3 件は 平面形 c であり、延べ床面積は $72.81 \mathrm{~m}^{2} \sim 96.36 \mathrm{~m}^{2}$ である。

居住者「01」の住居以外の建築物は納屋を 1 件、高床倉庫 1 件、 熊檻 3 件、イナウを所有している（図 9）。居住者「02」及び「10」 の 2 名は、高床倉庫 1 件、熊檻 1 件、イナウを所有し、居住者「09」 は、高床倉庫 1 件、熊檻 1 件を所有している（図 10）。

\section{(2)「その他の人」が所有する建築物}

「その他の人」の住居は、平面形 $\mathrm{a}$ や平面形 $\mathrm{a}$ に小庇程度の付属 屋を伴った平面形 $\mathrm{b}-1$ 及び平面形 b-2 であり、延べ床面積は 12.60 $\mathrm{m}^{2} \sim 59.03 \mathrm{~m}^{2}$ と「村長及び村長に準ずる人」の住居より小さい。 建築物の所有状況を大きく分類すると、「住居のみを所有する人々 (図 11)」9 名と「住居及び住居以外の建築物 ${ }^{22}$ （「平地式寄棟建築 物」1名と「平地式切妻建築物」6 名) を所有する人々（図 12）」7 名の 2 つに分けられる。

\section{（2）所有する建築物の比較（表 7)}

「村長及び村長に準ずる人」と「その他の人」が所有する住居を 比較すると、住居の延べ床面積、主屋の規模、セムの規模に違いが 見られた。「村長及び村長に準ずる人」の所有する住居の延心゙床面

\section{表 6 建築物の所有状況}

\begin{tabular}{|c|c|c|c|c|c|c|c|c|c|}
\hline \multicolumn{2}{|c|}{ 居住者分類 } & \multicolumn{3}{|c|}{ 住居分類 } & \multicolumn{5}{|c|}{ 住居以外の建築物の有無 } \\
\hline 居住者 & 分類 & $\begin{array}{c}\text { 平地式 } \\
\text { 寄棟 }\end{array}$ & 平面形 & $\begin{array}{l}\text { 延へ床 } \\
\text { 面積 }\left(\mathrm{m}^{2}\right)\end{array}$ & $\begin{array}{l}\text { 平地式 } \\
\text { 建築物 }\end{array}$ & $\begin{array}{c}\text { 平地式 } \\
\text { 切妻 }\end{array}$ & $\begin{array}{l}\text { 高床 } \\
\text { 倉庫 }\end{array}$ & 熊檻 & イナウ \\
\hline 01 & \multirow{4}{*}{$\begin{array}{l}\text { 村長及び } \\
\text { 村長に } \\
\text { 準ずる人 }\end{array}$} & $\square 01 \mathrm{H}$ & 平面形a & 96.36 & $\square 015$ & 無し & O01P & $\begin{array}{r}01 B-1 \\
0.01 B-2 \\
0 \\
01 B-3 \\
\end{array}$ & 011 \\
\hline 02 & & $\square 02 \mathrm{H}$ & 平面形c & 82.94 & 無し & 無し & $02 \mathrm{P}$ & $02 \mathrm{~B}$ & 021 \\
\hline 10 & & $\square 10 \mathrm{H}$ & 平面形c & 78.00 & 無し & 無し & 10P & $10 \mathrm{~B}$ & \\
\hline 09 & & $\square 09 \mathrm{H}$ & 平面形 & 72.81 & 無し & 無し & $09 \mathrm{P}$ & $09 B$ & 無し \\
\hline 03 & \multirow{10}{*}{$\begin{array}{c}\text { その他の人 } \\
(9 \text { 名) }\end{array}$} & $\square 03 \mathrm{H}-1$ & 平面形公 & 48.00 & 無保 & 無L & 無C & 無C & \\
\hline & & $\square 03 \mathrm{H}-2$ & 平面形 & 42.70 & 無し & 無し & 無し & 無し & 無し \\
\hline 06 & & $\square 06 \mathrm{H}$ & 平面形 & 43.66 & 無し & 無し & 無し & 無し & 無し \\
\hline 11 & & $\square 11 \mathrm{H}$ & 平面形 $\mathrm{a}$ & 37.70 & 無し & $\begin{array}{l}\text { 無し } \\
\end{array}$ & 無し & 無し & 無し \\
\hline 12 & & $\square 12 \mathrm{H}$ & 平面形 $\mathrm{a}$ & 32.40 & 無し & 無し & 無し & 無し & 無L \\
\hline 13 & & $\square 13 \mathrm{H}$ & 平面形a & 31.20 & 無L & 無し & 無L & 無し & 無L \\
\hline 19 & & $\square 19 \mathrm{H}$ & 平面形 $\mathrm{a}$ & 29.40 & 無し & 無し & 無し & 無し & 無し \\
\hline 17 & & $\square 17 \mathrm{H}$ & 平面形a & 12.60 & 無し & 無L & 無し & 無し & 無L \\
\hline 14 & & $\square 14 \mathrm{H}$ & 平面形b-1 & 36.74 & 無し & 無し & 無し & 無し & 無し \\
\hline 07 & & $\square 07 \mathrm{H}$ & 平面形 $\mathrm{b}-2$ & 24.24 & 無L & 無し & 無し & 無し & 無L \\
\hline 20 & \multirow{7}{*}{$\begin{array}{c}\text { その他の人 } \\
\text { (7名) }\end{array}$} & $\square 20 \mathrm{H}$ & 平面形 $\mathrm{a}$ & 33.60 & 無し & $\Delta g$ & 無し & 無し & 無し \\
\hline 18 & & $\square 18 \mathrm{H}$ & 平奤形a & 19.61 & 無し & $\bar{\Delta} f$ & 無L & 無し & 無L \\
\hline 08 & & $\square 08 \mathrm{H}$ & 平面形b-1 & 59.03 & 無し & $\overline{\Delta b}$ & 無し & 無し & 無し \\
\hline 04 & & $\square 04 \mathrm{H}$ & 平面形b-1 & 51.84 & 無し & $\overline{\Delta a}$ & 無し & 無し & 無し \\
\hline 15 & & $\square 15 \mathrm{H}$ & 平面形b-1 & 43.74 & 無し & $\overline{\Delta c}$ & 無し & 無し & 無L \\
\hline 16 & & $\square 16 \mathrm{H}$ & 平面形b-1 & 52.44 & 無し & $\boldsymbol{\mathbf { \Delta }} \mathrm{d}, \boldsymbol{\Lambda} \mathrm{e}$ & 無し & 無し & 無し \\
\hline 05 & & $\square 05 \mathrm{H}$ & 平面形 $\mathrm{b}-1$ & 48.90 & $\square 055$ & $\begin{array}{l}\text { 無し } \\
\end{array}$ & 無し & 無し & 無し \\
\hline
\end{tabular}

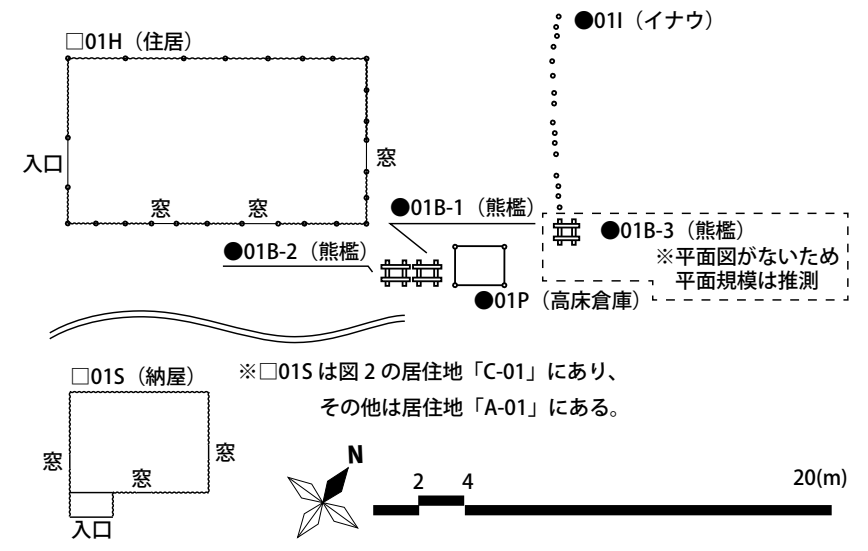

図 9 「村長及び村長に準ずる人」の建築物の配置図（居住者「01」）

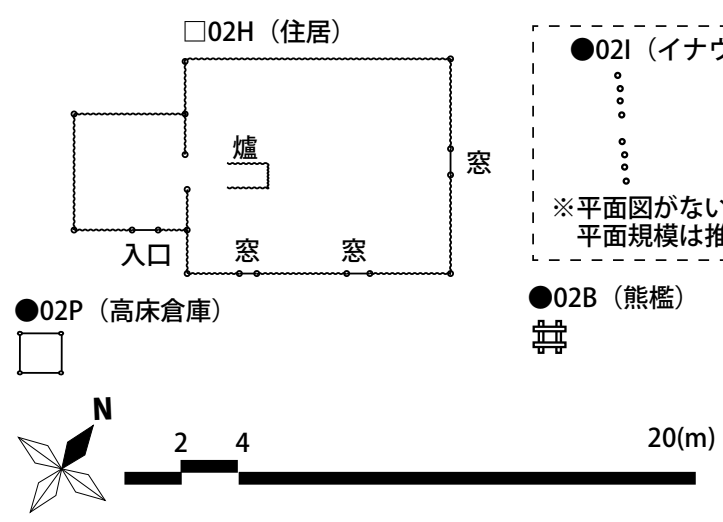

図 10 「村長及び村長に準する人」の建築物の配置図（居住者「02」）
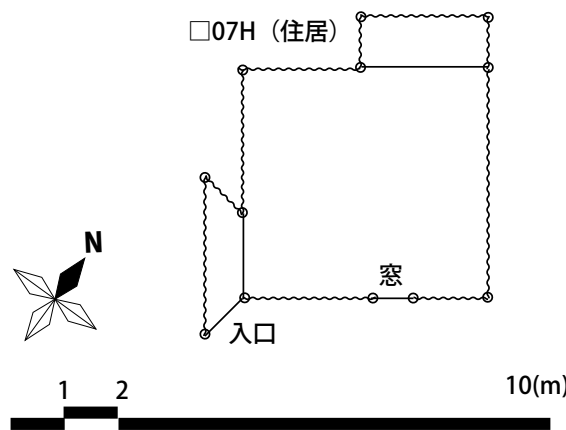

図 11 「その他の人」の建築物の配置図（居住者「07」）

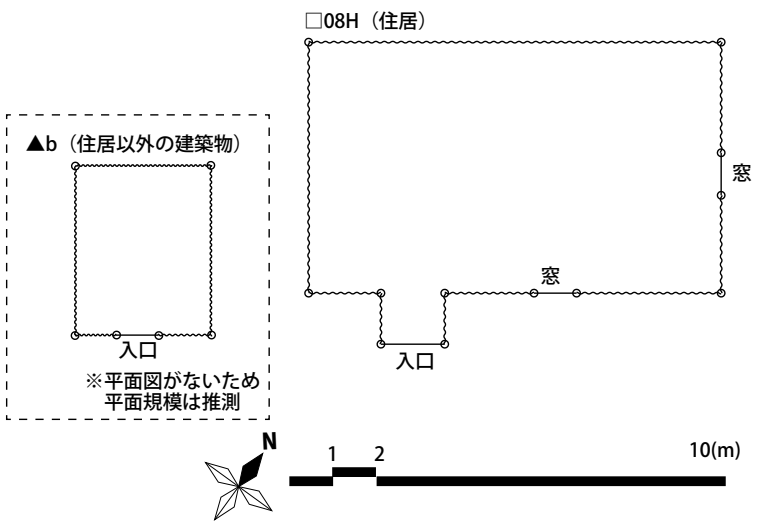

図 12 「その他の人」の建築物の配置図（居住者「08」） 
積は $72.81 \mathrm{~m}^{2} \sim 96.36 \mathrm{~m}^{2}$ 、主屋の規模は $60.72 \mathrm{~m}^{2} \sim 96.36 \mathrm{~m}^{2}$ 、セ ムが接続する住居におけるセムの形状は寄棟屋根の玄関 (室) で (平 面形 c のセム)、セムの規模は $12.09 \mathrm{~m}^{2} \sim 17.20 \mathrm{~m}^{2}$ あるる。一方で 「その他の人」の所有する住居の延べ床面積は $12.60 \mathrm{~m}^{2} \sim 59.03 \mathrm{~m}^{2}$ 、 主屋の規模は $12.60 \mathrm{~m}^{2} \sim 57.23 \mathrm{~m}^{2}$ 、セムが接続する住居における セムの形状は片流れ及び切妻屋根の小庇で（平面形 $\mathrm{b} 1$ 及び平面形 b2 のセム)、セムの規模は $0.80 \mathrm{~m}^{2} \sim 8.36 \mathrm{~m}^{2}$ であり、延べ床面積、 主屋の規模、セムの規模（セムの形状も含む）の全てが「村長及び 村長に準ずる人」の所有する住居より小さい。

「村長及び村長に準ずる人」及び「その他の人」の所有する住居 に共通して見られた特徵は、住居配置は主屋長軸が各土地区画上の 東西軸にあたり、入口が平入では南で妻入では西にあった事、採光 用に南空を 1 〜 2 設け、神空として東空を 1 つ設ける空位置が「村 長及び村長に準ずる人」の住居の全て、「その他の人」の住居 17 件 中 12 件（件数比 $70.6 \%$ ）に見られた事である（なお、主屋の規模 が $50 \mathrm{~m}^{2}$ 以上の住居は、「村長及び村長に準ずる人」の住居 4 件と 「その他の人」の住居 2 件の計 6 件あり、内 5 件が南空を 2 つ設け ている事から、主屋の規模の大きな住居の南面に空を 2 つ設置する 特徵も見られる)。また、1937 年に北海道旧土人保護法の一部を改 正し、アイヌ民族に対して住宅改良のための資金を支給する制度が 定められたことによる影響と考えられる、「マサ壁」や「ガラス空」 を備えた住居は、「村長及び村長に準ずる人」の住居 4 件の内 2 件 (件 数比 $50 \%$ )、「その他の人」の住居 17 件の内 8 件（件数比 $47.1 \%$ ) に見られた。

住居以外の建築物の所有状況を見ると、「村長及び村長に準ずる 人」は「高床倉庫」や「熊檻」や「イナウ」等の「付属建築物」を 全員が所有するのに対し、「その他の人」は「付属建築物」を所有せず、 「平地式切妻建築物」の所有（16 名の内 6 名）と「平地式寄棟建築物」 の所有（16 名の内 1 名）であった。

\section{8. 結論}

本研究は、「毛民青屋集」 7 ～8 を基にして、下附実測図 (1912 年)、 コタン図（1926 年から 1937 年)、空中写真（1944 年）を検討する 事により、1940 年の白老村アイヌ集落の土地区画の特徵、白老村 アイヌ集落の居住者 20 名の「平地式寄棟建築物」 23 件、「平地式 切妻建築物」 7 件、「付属建築物」 13 件の計 43 件の建築物の外観 の特徵、平面規模の特徵、建築物の所有状況を明らかにした。

白老村アイヌ集落の土地区画は、2 本の南北道路（南北軸から反 時計回りに凡そ 30 度の傾きがある）と南北道路に垂直な 4 本の東 西道路が交わった土地に対し、1 区画 450 坪（15 間× 30 間）を基 本に区画整備され、1940 年時におけるアイヌ民族に割り渡されて いた給与地は、1世帯に 1 区画（坪数は凡そ 450 坪）を基本として いたと考えられる。

一方で建築物においては、「村長及び村長に準ずる人」と「その 他の人」に居住者を分類すると違いが見られた。「村長及び村長に 準ずる人」が所有した住居は、延べ床面積、主屋の規模、セムの規 模において「その他の人」が所有した住居より大きく、また、住居 の他に「高床倉庫」や「熊檻」や「イナウ」の「付属建築物」を所 有していたのに対し、「その他の人」が所有した建築物は住居のみ の所有もしくは住居と「平地式切妻建築物」か「平地式寄棟建築物」
表 7 所有する建築物の比較

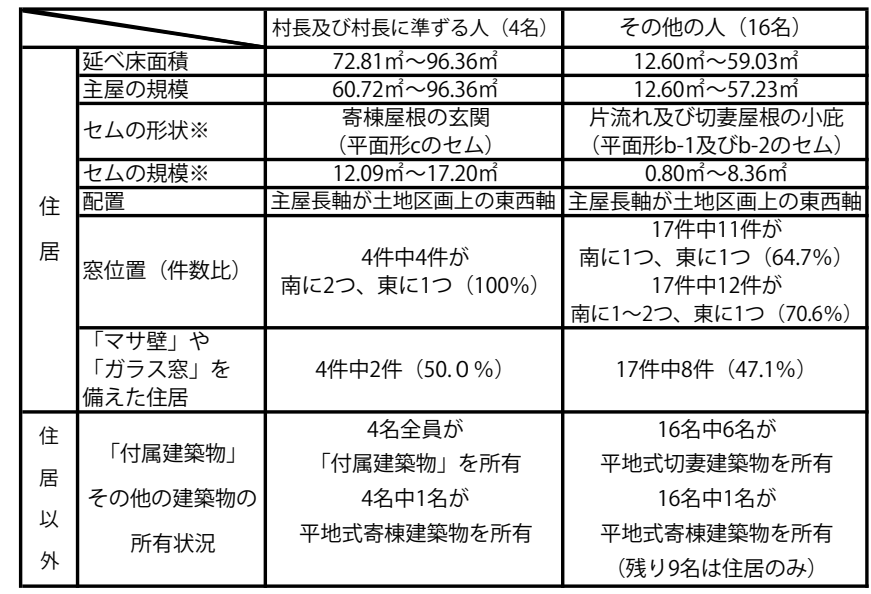

※セムの形状及びセムの規模は、各所有者の住居の内、セムを伴う住居を対象と している。なお、「村長及び村長に準ずる人」の住居の 4 件中 1 件、「その他の人」 の住居の 17 件中 10 件は、セムを伴わない平面形（平面形a）である。

の所有であった。なお「高床倉庫」は、柱を建て込み高床を設け、 その上に檻本体を乗せた、高床と倉庫が分離する構造（高床式・分 離型）であり、屋根形状は寄棟屋根と切妻屋根が見られた。「熊檻」 は、柱を建て込み高床を設け、その上に檻本体を乗せた高床と檻 が分離している構造（高床式・分離型）、柱を建て込み高床を設け 周囲に丸太を井桁状に組む構造（高床式・一体型）、柱を建て込み、 地上から周囲に丸太を井枌状に組む構造（平地式・一体型）の 3 構 造が見られた。「イナウ」は住居の東側に位置し、住居の東空 (神空) からのぞく事ができた。平地式切妻建築物」は住居の西側に位置し、 セムの伴わない矩形平面で、壁は茅壁で、空は設けていなかった。

「村長及び村長に準ずる人」と「その他の人」が所有した住居に 共通して見られた特徵は、住居配置は主屋長軸が各土地区画の東西 軸にあたり、入口は平入では南で妻入では西に位置していた事であ る。また、採光用に南空を 1 ～2 設け、神空として東空を 1 つ設 ける空位置は共に 7 割以上に見られ、「マ壁」や「ガラス空」を 備えた住居は共に 5 割程に見られた事である。

注

1) 新白老町史下巻を参考とした。白老町町史編さん委員会: 新白老町史下巻, 第一法規出版株式会社，1992 年 11 月 3 日.

2) 主な皇族の来訪者は以下の通りである。1918 年の閑院宮載仁親王殿下、 1928 年の徳川喜久子姫、1932 年の澄宮殿下、1934 年の北白川永久王殿下、 1936 年の朝香宮鳩彦王殿下等。主な研究者は、棚橋諒氏、鷹部屋福平氏、 杉野謙三氏等であり、1940 年前後に白老村を訪れている。

3) 鷹部屋福平氏は構造力学の研究者・北海道帝国大学工学部教授であり、ま た、アイヌ民族の建築に関する研究の第一人者である。代表する研究は以 下の通りである。鷹部屋福平 : アイヌ屋根の研究と其構造原基體につい て, 北方文化研究報告, 第一輯, pp. 107-161，1939 年 3 月. 同 : アイヌ 住居の研究，北方文化研究報告，第二輯，pp. 1-123，1939 年 10 月. 同： アイヌ住居の研究 - アイヌ家屋の地方的特性 - , 北方文化研究報告, 第三 輯, pp. 209-265，1940 年 5 月。同：アイヌ民族の使用したる計量の単位 並びに「音」の名称に関する研究, 北方文化研究報告, 第四輯, pp. 113135,1941 年 2 月. 同: アイヌ住居の研究 - 日高平取方面に於ける地方性 - , 北方文化研究報告, 第五輯, pp. 103-142, 1941 年 7 月. 同 : アイヌの生活 文化，アルス，1942 年 6 月. アイヌの住居，彰国社，1943 年 3 月. 同 : 北方圈の家，彰国社，1943 年 12 月.

4) 鷹部屋福平氏の私家版写真帖であり、現在、所蔵先の確認できる「毛民 青屋集」は $5 \sim 6$ (二風谷村)、 $7 \sim 8$ (白老村) であり、北海道大学付属 図書館が所蔵する。「毛民青屋集」7 8 の北海道大学付属図書館の資料 
目録は以下の通りである。北海道大学北方関係資料総合目録 : 白老村写 真帖第 $1 \sim 2$ 冊（折本仕立）／鷹部屋福平（シラオイムラ シャシンチョ ウ ダイ 1-2 サッ (オリホン シタテ)), 成立年/昭和 15 年 (1940 年), 形態/ 112 枚 (各 $7.5 \times 11 \mathrm{~cm})$ 原, 資料注記/鷹部屋福平「毛民青屋集」 7〜8 (白老村アイヌ住居の写真集), 請求記号 /別・ア 720-Ta（北大北 方資料室)，収載目録名 /明治大正期北海道写真目録（明治大正期の北海 道・目録編), レコード ID / OB030130000000000。鷹部屋福平 : アイヌ住 居の研究 - 日高平取方面に於ける地方性 - , 北方文化研究報告, 第五輯, pp. 103-142，1941 年 7 月. なお、二風谷村については、以下の論文を参照。 佐久間学, 羽樑久夫 : 鷹部屋福平「毛民青屋集」に基づいた 1940 年の二 風谷村アイヌ集落に見られた建築物の実態, 日本建築学会計画系論文集, 第 79 巻, 第 706 号, 2014 年 12 月.

5) 園内はアイヌ民族の茅莫きの家（チセ）5棟を中心にかつての集落の様子 を伝えるとともに、チセ内ではアイヌの伝統芸能や手工芸の実演など、無 形文化の伝承保存・公開を行う点が特色となっている。(アイヌ民族博物 館 HP 参照 : http://www. ainu-museum. or. jp/index. html)

6) 本研究において、伝統的なアイヌ民族の建築物とは、現在復元されている 茅莫屋根の茅壁といった定説的なアイヌ民族の建築物を指す。

7) 1937 年 (昭和 12 年) に北海道旧土人保護法の一部を改正し、アイヌ民族 に対して住宅改良のための資金を支給する制度が定められており、以後、 アイヌ民族建築物の様相は、「マ壁」の建築物が見えたり、「ガラス空」 を設置した建築物が見えだしたと考えられる。本研究において、同化政策 の影響が現れた 1940 年当時のアイヌ民族の建築物とは、6) で示した建築 物の他、「マサ壁」や「ガラス空」等を設けていた建築物も含めた 1940 年 当時のアイヌ民族の建築物であることを意味する。

8) 鷹部屋福平 : アイヌ住居の研究 - アイヌ家屋の地方的特性 - , 北方文化研 究報告, 第三輯, pp. 209-265, 1940 年 5 月.

9) アイヌ民族の建築物に関する研究は、鷹部屋氏が研究した 1930 年代後半 から 1940 年代前半に集中している。代表的な研究は以下の通りである。 棚橋諒: アイヌの住居, 民家, 民家研究会, 第 II 輯 12 号, 1938 年 12 月. 同: アイヌの住居（2）民家，民家研究会，第而輯 1 号，1939 年 1 月。同 : アイヌの住居 (3), 民家, 民家研究会, 第亚輯 2 号、1939 年 2 月。杉野 謙三: アイヌ部落, 満州建築雑誌, 1940 年. 金田一京助 : アイヌ芸術, 木工編，1942 年. 村田治郎:アイヌの家の史的解釈, 建築学会大会梗概集, 1950 年 8 月. 同: 原始住居構造の一つの型, 建築雑誌, 775 号, 1951 年 7 月. 近年の研究には、小林孝二氏のアイヌ文化期を対象とする発掘報告書 と 18 世紀中期から 19 世紀後半にアイヌ民族の住居を描いた絵画資料を基 に、アイヌ文化成立期（13 世紀前後）から近世紀末（19 世紀後半）まで のアイヌ民族の住居の特徵を明らかにした研究がある。小林孝二, 大垣直 明 : 近代以前の絵画資料に描かれたアイヌ民族の建築に関寸る研究, 日本 建築学会計画系論文集, 第 608 号, pp. 127-134，2006 年 10 月. 同 : アイ 又文化期の平地住居跡に関する基䃈的研究 - 発掘資料から見たアイ又民族 住居の寸法体系に関寸る考察-, 日本建築学会計画系論文集, 第 615 号, pp. 191-198, 2007 年 5 月.

10)イナウはアイヌ民族の祭壇であり、白老村アイヌ集落のイナウの上部には 熊の骨をまつっている。

11）北海道立文書館が所蔵する手書地図。資料目録は以下の通りである。胆振 国白老郡白老村字コタン旧土人下附実測図: 請求記号/ $\mathrm{Ma}-1 / 2923$, 分類 / A 7-2 北海道庁_支庁 - 郡役所, 主務者名/北海道庁室蘭支庁, 年次 / $1912($ 明治 45$)$, 形態 $/ 1$ 枚 $(77 \times 86 \mathrm{~cm})$, 注記 $/$ 縮尺 $1: 1200$.

12）1）と同一資料。

13） 84 名（世帯）は、コタン図に描かれたアイヌ民族名を数えたものである。 補足として、下附実測図の各区画の姓とコタン図の記名箇所の姓が一致す る者は、84名の内 32 名いた。

14）国土地理院所蔵の空中写真。空中写真注記は以下の通りである。撮影年 / 1944 年 10 月 22 日 (昭和 19 年), 撮影実施機関/陸軍，整理番号/ 91Q32, コース番号 / C5, 写真番号/ 110.

15）北海道庁立白老病院の院長、高橋房次氏は、1937 年の旧土人保護法改正 によって白老病院が閉鎖された後も、同じ場所で「高橋医院」を開業し、 1960 年に医師の仕事を全うし 78 歳でこの世を去った。以下の資料を参考 とした。白老町町史編さん委員会 : 新白老町史上巻及び下巻, 第一法規出 版株式会社, 1992 年 11 月 3 日.

16）セムはアイヌ語で、主屋入口に接続する下屋（前室や庇や風除室の機能） をさす。本研究において、セムを伴わない建築物についても、屋根の小屋 組下の室を主屋と表記する。なお、アイヌ民族の建築物に関する第一人者 である鷹部屋氏と棚橋氏の両氏が論文において「セム」というアイヌ語を
用いている事から、本研究においても「セム」を用いている。鷹部屋氏の 研究は 3）を参照。棚橋氏の研究は9）を参照。

17) 平面形 a $「 \square \mathrm{H} 03-1 」$ 及び「 $\square 11 \mathrm{H} 」$ と平面形 $\mathrm{b}-2$ $2 「 \square 07 \mathrm{H} 」$ の主屋 平面形は、平側にセムとは異なる（入口に接続する下屋ではない）下屋を 突出する平面形であるが、主屋平面形は矩形平面と同等に扱った。

18) 平面図から入口及び空位置の他、入口幅と空幅が分かる。入口幅は 0.6 $1.6 \mathrm{~m}$ 、入口幅は 0.6 〜 $2.2 \mathrm{~m}$ まである。

19）1）と同一資料。

20）1）の資料である新白老町史から、村長の家系と東宮殿下の白老村来訪時 の案内役を務めたアイヌ民族の人々の 4 名の総称を「村長及び村長に準ず る人」と定義した。なお、「村長に準ずる人」について、村長の家系の居 住者「01」及び「10」が所有した建築物と村長の家系の他に案内役を務め た居住者「02」及び「09」の所有した建築物の特徴は共通し、「その他の 人 $(16$ 名 $) 」 か ゙$ 所有した建築物と異なるので、「村長」以外の案内役を務 めた人は「村長に準ずる人」であったと考えられることから定義している 4 名の人名は新白老町史に記載があるが、表 1 の調查票の記載内容の居住者 番号を用いている)。

21）配置図の建築物は、「毛民青屋集」7～8 の調査票に添付されている平面 図を基に作製し、寸法表記は省略し、代わりにスケールを表記している。 な㧍、図 9 の 01B-3（熊檻）、図 10 の 02I（イナウ）、図 12 の $\mathrm{\Delta}$ b (平 地式切妻建築物）については、調查票に平面図が添付されていないため、 写真から建築物の位置関係と平面規模を推測して表記してある。

22) 住居以外の建築物のうち「平地式寄棟建築物」の用途は、鷹部屋氏の記載 から納屋であった事が分かる。 


\section{Manabu SAKUMA* and Hisao HABUKA**}

* Graduate Student, Graduate School of Design, Sapporo City University, M. Des.
** Prof., Graduate School of Design, Sapporo City University, Dr. Eng.

This study, based on Collection of Thatched-Roof Houses of the Ainus Volumes 7 through 8 and conducted through the investigation of old maps and aerial photographs, reveals layout features and features of building appearance, surface scale, and ownership details of the Shiraoi Village Ainu settlement in 1940.

The Shiraoi Village Ainu settlement was laid out such that there were two north-south roads and four east-west roads intersecting perpendicularly to form a grid. A single section area was maintained to be approximately 1,485 square meters $(27 \mathrm{~m}$ x $55 \mathrm{~m}$ ). The settlement that Takabeya investigated in 1940 was divided among the villagers such that each Ainu family household was allotted one section of land.

Another avenue of investigation was conducted by way of examining village houses. There were observed differences in house design upon separating villagers into either "village chief/equivalent" or "other people" categories. Houses belonging to "village chief/equivalent" villagers had elongated floor space and both the main and auxiliary structures were larger in scale than those belonging to the "other people" villagers. Furthermore, "village chief/equivalent" villagers owned structures such as elevated storehouses, bear pens, and attached buildings containing inaws (ritual prayer sticks). "Other people" villagers did not possess such structures and what they did possess was apparently intended only for habitation. It is also possible that gabled roof houses were used both for habitation as well as for auxiliary activities.

In addition, there were traits common among the houses of both groups. For example, construction was arranged such that houses had their longer axis parallel to the east-west axis of the settlement. One or two windows were installed facing south in order to maximize lighting. Houses with an east-facing "holy window" had seven or more partitions. Finally, houses containing walls made from the Japanese spindletree (Euonymus japonicus) and possessing a glass window were divided into five partitions. 